JURNAL RISET REKAYASA ELEKTRO

Vol.2, No.2, Desember 2020, Hal. 59 68

P-ISSN: 2685 - $4341 \quad$ E-ISSN: 2685 - 5313

\title{
Penerapan Internet of Things (IoT) pada Sistem Pengendali dan Pengaman Pintu Berbasis Android
}

\author{
Dian Nova Kusuma Hardani ${ }^{1}$, Latiful Hayat ${ }^{2}$ \\ Program Studi Teknik Elektro S-1, Universitas Muhammadiyah Purwokerto \\ Fakultas Teknik dan Sains, Universitas Muhammadiyah Purwokerto
}

\section{Informasi Makalah}

Dikirim, 19 November 2020

Direvisi, 17 Desember 2020

Diterima, 29 Desember 2020

Kata Kunci:
Smartphone
IoT
Internet
Electronic Door Lock
Pengendali
Pengaman

\section{Kata Kunci:}

IoT

Internet

Pengendali

Pengaman

\begin{abstract}
INTISARI
Seiring perkembangan teknologi, smartphone menjadi salah satu platform yang digunakan orang tidak hanya untuk terhubung dengan orang lain, juga untuk memantau segala sesuatu di sekitarnya dalam segala aspek melalui koneksi internet. Teknologi IoT juga dapat diterapkan dalam membuat konsep baru dan ruang pengembangan yang luas yang diimplementasikan pada rumah pintar untuk menyediakan kenyamanan, keamanan dan meningkatkan kualitas hidup. Salah satu aplikasi IoT adalah untuk keamaan rumah. Sistem keamanan rumah sudah menjadi sebuah kebutuhan mutlak agar bisa terhindar dari tindak kejahatan. Pada penelitian ini, smartphone dapat digunakan untuk memantau dan mengontrol aksesibilitas pintu dari mana saja melalui koneksi internet. Prototipe yang terhubung ke platform IoT memungkinkan pengguna dapat mengunci dan membuka kunci pintu dari jarak jauh. Sistem akan bekerja jika mikrokontroler ESP8266 telah mendapatkan supply tegangan dan arus sebesar 5 volt. Metode yang digunakan pada penelitian ini yaitu memanfaatkan wifi untuk inisialisasi fingerprint sensor dan solenoid, mengakses sistem, membaca permintaan dan melanjutkan perintah membuka pintu. Hasil menunjukkan bahwa Electronic Door Lock (EDL) mulai mampu mengunci pintu pada tegangan 9 Volt dengan arus $258 \mathrm{~mA}$. Walaupun indikator EDL mulai menyala pada tegangan 2,3 Volt, namun megnetisasi masih lemah sehingga selenoid tidak mampu menarik besi yang dipasang pada pintu. Sistem pengendali dan pengaman pintu dapat dimonitor melalui smartphone atau website jika proses enrollment berhasil. Sistem ini dapat mengintegrasikan sirkuit low power yang dibangun dengan perangkat akses pintu dan platform IoT.
\end{abstract}

\section{Keyword:}

Smatphone

IoT

Internet

Controller

Histogram

\begin{abstract}
Along with technological developments, smartphones have become one of the platforms that people use to connect with other people and monitor everything around them in all aspects through an internet connection. IoT technology can also be applied in creating new concepts and broad development spaces implemented in smart homes to provide comfort, safety, and improve quality of life. One of the IoT applications is for home security. Home security systems have become an absolute necessity to avoid crime. In this study, smartphones can monitor and control door accessibility from anywhere via an internet connection. The prototype connected to the IoT platform allows users to remotely lock and unlock doors. The system will work if the ESP8266 microcontroller has received a voltage and current supply of 5 volts. The method used in this study is to use wifi to initialize fingerprint sensors and solenoids, access the system, read requests, and continue the door opening command. The results show that the Electronic Door Lock (EDL) starts to lock the door at a voltage of 9 volts with a current of $258 \mathrm{~mA}$. Even though the EDL indicator starts to turn on at a voltage of 2.3 Volt, the magnetization is still weak, so that the selenoid is unable to attract the iron mounted on the door. The door control and security system can be monitored via a smartphone or website if the enrollment process is successful. This system can integrate low power circuits built with door access devices and IoT platforms.
\end{abstract}




\author{
Korespondensi Penulis: \\ Dian Nova Kusuma Hardani \\ Program Studi Teknik Elektro \\ Fakultas Teknik dan Sains Universitas Muhammadiyah Purwokerto \\ JL. K.H. Ahmad Dahlan, Purwokerto, 53182 \\ Email: stufi1983@gmail.com
}

\title{
1. PENDAHULUAN
}

Teknologi saat ini berkembang sangat pesat, dan dapat dirasakan dalam dunia industri maupun masyarakat. Salah satunya yaitu dengan pemanfaatan teknologi Internet of Things (IoT). IoT adalah konsep yang muncul di mana semua alat dan layanan terhubung satu dengan yang lain dengan mengumpulkan, bertukar dan memproses data untuk beradaptasi secara dinamis. IoT dapat digambarkan sebagai penghubung objek sehari-hari seperti smartphone, TV Internet, sensor dan aktuator ke Internet tempat perangkat secara cerdas dihubungkan bersama memungkinkan bentuk komunikasi baru antara objek dan orang-orang, atau antara objek itu sendiri [1].

Pemanfaatan IoT sudah banyak dilakukan. IoT yang diterapkan pada kendali lampu, hidup dan matinya lampu berjalan secara otomatis, sehingga manusia hanya berperan sebagai pengatur dan pemantau berkerjannya alat [2]. Selain lampu, perangkat elektronik juga dapat dikontrol dengan menerapkan IoT seperti AC dan TV sehingga dapat mengurangi adanya pemborosan listrik ketika pengguna lupa untuk mematikan peralatan elektronik rumah tangga ketika keadaan di luar rumah atau dimanapun pengguna berada [3]. IoT juga dapat digunakan untuk pengendali dan pemantau kendaraan secara realtime. Perangkat IoT dilengkapi aplikasi yang akan dikoneksikan dengan server Firebase dan selanjutnya dipasang pada kendaraan. Jika kendaraan dihidupkan maka alat IoT akan mengirimkan data posisi kendaraan dari satelit GPS ke server Firebase [4].

Penelitian sistem keamanan rumah menggunakan IoT telah dilakukan. Sistem keamanan akan menggunakan mikrokontroler yang dikenal sebagai Arduino Uno untuk antarmuka antara komponen, sensor Reed magnetik untuk memantau status, bel untuk membunyikan alarm, dan modul WiFi ESP8266 untuk menghubungkan dan berkomunikasi menggunakan Internet. Keuntungan utama dari sistem tersebut termasuk kemudahan pengaturan, biaya lebih rendah dan perawatan yang rendah [5]. Selain itu, penelitian serupa menggabungkan mikrokontroller dengan smartphone android dan magnetic door switch sensor, mikrokontroller yang digunakan adalah arduino uno yang dilengkapai dengan sim808. Sim808 akan menghasilkan notifikasi berupa suara, SMS dan akan mengirim data ke database server, hasil yang dikirim ke database dapat dilihat melalui sebuah aplikasi yang menampilkan kapan pintu terbuka. Dengan sistem keamanan rumah ini memungkinkan untuk mengetahui kapan pintu terbuka ketika sedang tidak di rumah [6]. Sistem keamanan rumah sudah menjadi sebuah kebutuhan mutlak agar bisa terhindar dari tindak kejahatan.

Saat ini, orang bisa mendapatkan akses ke internet dari mana saja di seluruh dunia. Banyak perangkat dapat memiliki akses ke internet terutama dari smartphone. Seiring perkembangan teknologi, smartphone menjadi salah satu platform yang digunakan orang tidak hanya untuk terhubung dengan orang lain, juga untuk memantau segala sesuatu di sekitarnya dalam segala aspek melalui koneksi internet. Teknologi IoT juga dapat diterapkan dalam membuat konsep baru dan ruang pengembangan yang luas yang diimplementasikan pada rumah pintar untuk menyediakan, kenyamanan, keamanan dan meningkatkan kualitas hidup. Adanya teknologi IoT menjadikan implementasi dari rumah pintar atau lebih dikenal dengan istilah smart home menjadi kian popular.

Tujuan utama dari penelitian ini adalah untuk mengembangkan dan mengimplementasikan teknologi IoT pada sistem pengendali dan pengaman pintu berbasis android. Sistem dapat mengintegrasikan sirkuit low power yang dibangun dengan perangkat akses pintu dan platform IoT. Perbedaan dari penelitian sebelumnya bahwa penelitian ini yang didasarkan pada integrasi IoT, memungkinkan smartphone untuk memantau dan mengontrol aksesibilitas pintu dari mana saja, ketersediaan backup baterai dan penggunaannya, serta berbagai aktivitas yang dilakukan oleh sistem dapat termonitor melalui koneksi internet. Prototipe yang terhubung ke platform IoT dan memungkinkan pengguna dapat mengunci dan membuka kunci pintu dari jarak jauh. Itu tidak terbatas pada koneksi internet yang sama. Prototipe akan dapat beroperasi bahkan dengan koneksi internet yang berbeda seperti yang digunakan smartphone. 


\section{METODE PENELITIAN}

Perancangan proses alur kerja sistem diharapkan mampu menjadikan sistem pengaman pintu yang dibuat dapat berjalan dengan baik. Pada proses perancangan ini dibagi menjadi dua tahapan, yaitu tahap perancangan hardware dan perancangan software. Adapun penjelasan masing-masing tahapan sebagai berikut.

\subsection{Perancangan Hardware}

Sistem hardware yang dibutuhkan untuk pengendali dan pengaman pintu antara lain mekanik pengunci pintu yang menggunakan solenoid sebagai komponen utamanya, backup baterai, microcontroller unit (MCU), sensor Passive Infrared (PIR), dan sensor sidik jari untuk enrollment data. Setiap hardware pada sistem ini didesain dan diujicoba terlebih dahulu agar sesuai dengan kebutuhan sistem, sehingga sistem dapat terintegrasi satu sama lain dengan baik. Adapun langkah-langkah yang dilakukan dalam membangun sistem hardware ditunjukkan pada Gambar 1.

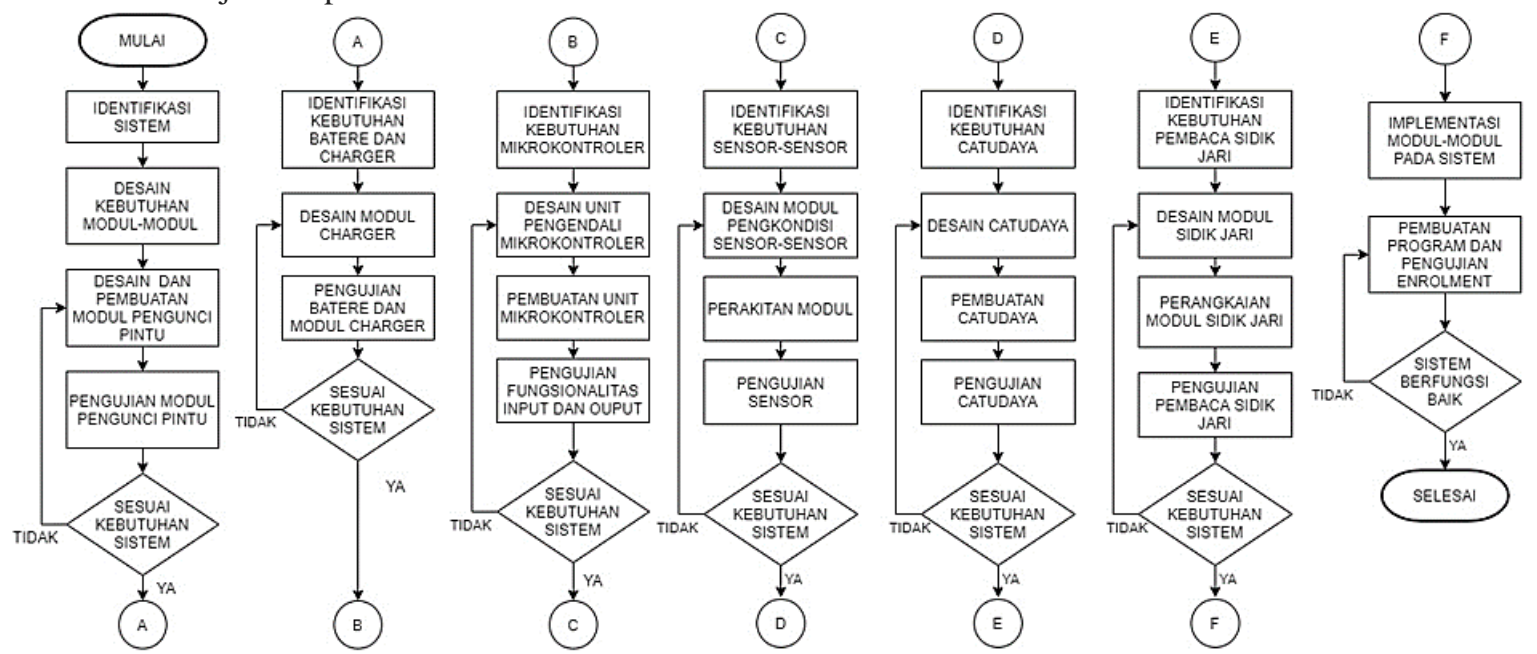

Gambar 1. Flowchart Aliran Kerja Perancangan Sistem Hardware

Langkah pertama dilakukan perancangan modul pengunci pintu sesuai dengan kebutuhan sistem. Jika pengujian berhasil, langkah selanjutnya yang dilakukan adalah mendesain modul charger dengan mengidentifikasi kebutuhan baterai terlebih dulu. Setelah diuji coba modul charger, langkah berikutnya mendesain pengendali berupa unit mikrokontroler dan menguji fungsi input-outpunya. Apabila sudah sesuai dengan kebutuhan sistem, lanjut ke tahap berikutnya yaitu mendesain modul pengkondisi sensor PIR dan melakukan pengujian. Langkah berikutnya adalah mendesain catudaya yang digunakan untuk mengaktifkan pengunci kunci pintu. Setelah selesai menguji modul catudaya, desain modul sidik jari dibuat untuk pengaman pintu. Langkah akhir pada pembuatan sistem pengendali ini adalah mengimplementasikan semua modul yang telah dibuat dan diuji menjadi satu sistem pengaman pintu. Proses perekaman dan pengujian biometric sidik jari atau enrollment dibutuhkan untuk dapat mengakses atau masuk melalui pintu tersebut.

\subsection{Perancangan Software}

Alur kerja program akan menjelaskan aliran kerja perangkat software dalam mengendalikan kerja hardware, sehingga dapat dikatakan bahwa perangkat software memberikan peranan yang besar pada sistem. Gambar 2 merupakan penjelasan cara kerja sistem. Proses perancangan sistem dimulai dengan persiapan segala kebutuhan sistem, mulai dari persiapan alat dan bahan, desain rangkaian yang dibutuhkan untuk menunjang kerja sistem, pembuatan layout pada PCB merupakan langkah pembuatan dari skematik rangkaian komponen elektronik menjadi rangkaian papan (board) PCB, pemasangan komponen pada papan (board) PCB yang telah dibuat dan pemasangan pada bagian pintu yang telah ditentukan, dan pengujian setiap rangkaian yang telah dibuat.

Langkah selanjutnya adalah inisialisasi fingerprint. Setelah itu, sistem akan meminta Wifi untuk mengakses sistem, jika YA maka sistem akan membaca permintaan dan melanjutkan perintah membuka. Jika YA maka solenoid akan membuka dan menampilkan status UNLOCK. Selang beberapa detik pintu akan terkunci kembali. Jika kondisinya permintaan deteksi Wifi tidak dapat terpenuhi, maka sistem akan meminta mendeteksi fingerprint, data valid atau tidak. Jika TIDAK maka harus dilakukan scan ulang. Jika data tersebut valid maka sistem akan membaca Non-volatile Memory (NVW) data (data yang ada di memori). Jika data 
NVW dan fingerprint sama maka solenoid akan membuka. Jika data tidak sama maka sistem akan meminta data fingerprint atau keypad lagi.

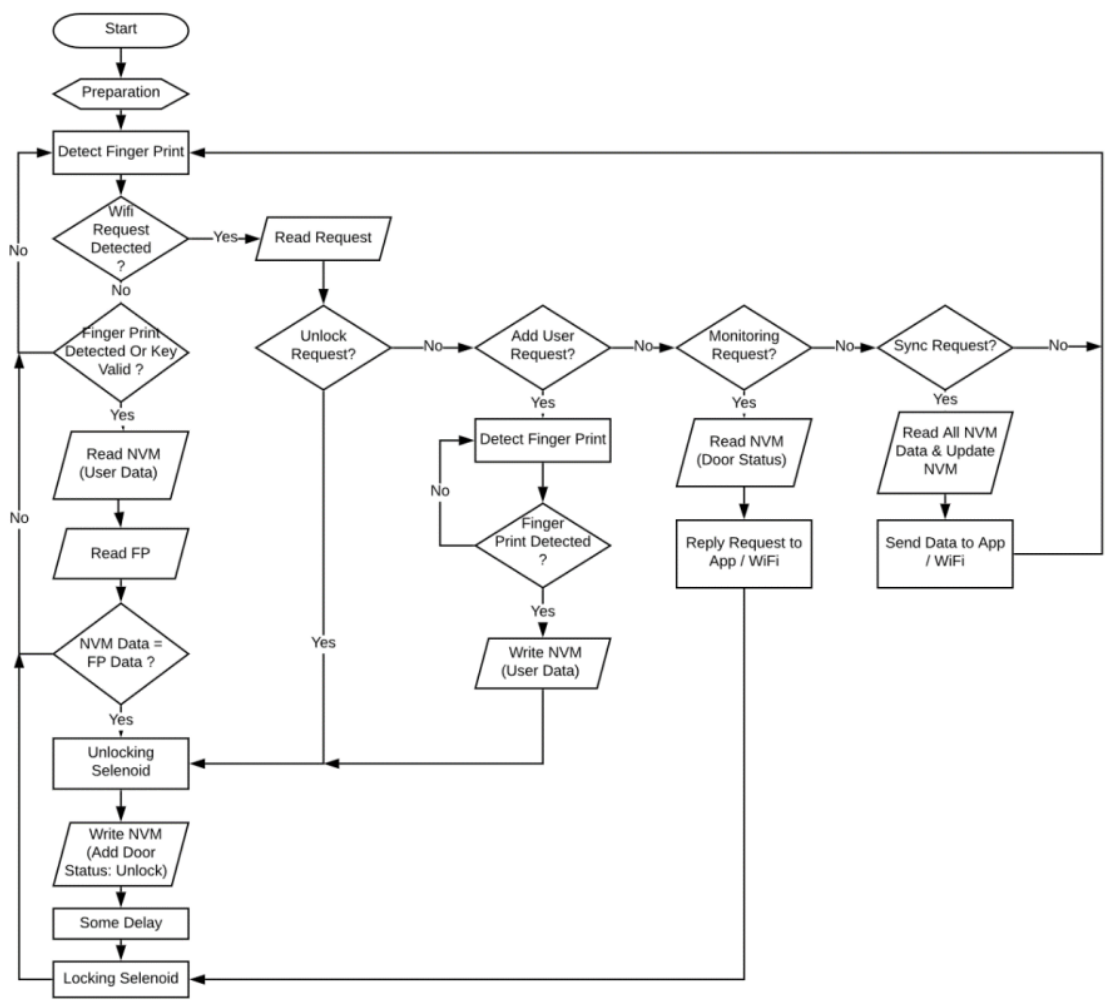

Gambar 2. Flowchart Aliran Kerja Perangkat Software

\section{HASIL DAN PEMBAHASAN} berikut.

Rangkaian prosedur penelitian yang telah dilakukan dan hasil penelitiannya dapat dijelaskan sebagai

\subsection{Mekanik Pengunci Pintu}

Pengujian dilakukan dengan memberikan tegangan dari 0 Volt hingga 13 Volt menggunakan catu daya output tegangan variabel merk Ongli Fixtool PS305DM. Pada Catudaya tersebut sudah terdapat Voltmeter dan Amperemeter, sehingga memudahkan dalam proses pengujian. Hasil dari pengujian dapat disimpulkan bahwa Electronic Door Lock mulai mampu mengunci pintu pada tegangan 9 Volt dengan arus $258 \mathrm{~mA}$. Walaupun indikator EDL mulai menyala pada tegangan 2,3 Volt, namun meagnetisasi masih lemah sehingga selenoid tidak mampu menarik besi yang dipasang pada pintu. Semakin besar tegangan yang dicatukan ke selenoid, semakin besar pula arus yang mengalir seperti ditunjukkan pada Tabel 1.

Tabel 1. Hasil pengujian selenoid door lock

\begin{tabular}{ccccc}
\hline NO & $\begin{array}{c}\text { Tegangan } \\
(\text { Volt })\end{array}$ & $\begin{array}{c}\text { Arus } \\
(\mathbf{m A})\end{array}$ & Lampu Indikator Selenoid & Kondisi Pintu \\
\hline 1 & 0 & 0 & Mati & Tidak Terkunci \\
2 & 1 & 5 & Mati & Tidak Terkunci \\
3 & 2 & 35 & Mati & Tidak Terkunci \\
4 & 2,3 & 44 & Nyala & Tidak Terkunci \\
5 & 3 & 65 & Nyala & Tidak Terkunci \\
6 & 4 & 96 & Nyala & Tidak Terkunci \\
7 & 5 & 120 & Nyala & Tidak Terkunci \\
8 & 6 & 157 & Nyala & Tidak Terkunci \\
9 & 7 & 190 & Nyala & Terkunci, terbuka saat didorong \\
10 & 8 & 224 & Nyala & Terkunci \\
11 & 9 & 258 & Nyala & Terkunci \\
12 & 10 & 293 & Nyala & Terkunci \\
13 & 11 & 324 & Nyala & Terkunci \\
14 & 12 & 357 & Nyala & Terkunci \\
15 & 13 & 387 & Nyala &
\end{tabular}




\subsection{Backup Baterai}

Baterai yang digunakan adalah jenis baterai Li-Po dengan kapasitas $500 \mathrm{mAh}$ tegangan kerja 11,1 V (3 Cell) dengan suhu kerja $25^{\circ} \mathrm{C}$. Dalam pengujian ini, baterai pada awalnya diisi hingga penuh menggunakan charger. Charger yang digunakan adalah LiPo charger $800 \mathrm{~mA}$ per Cell. Selanjutnya baterai dibebani dengan beban hambatan 4,5 Ohm. Hambatan 4,5 Ohm dipilih agar pada saat pengujian baterai dapat dilakukan dengan waktu singkat menghantarkan arus 2A secara kontinyu saat tegangan 9 Volt. Waktu pengosongan baterai secara kasar dapat dikalikan dengan 2 jika penggunaan arus baterai adalah $1000 \mathrm{~mA}$.

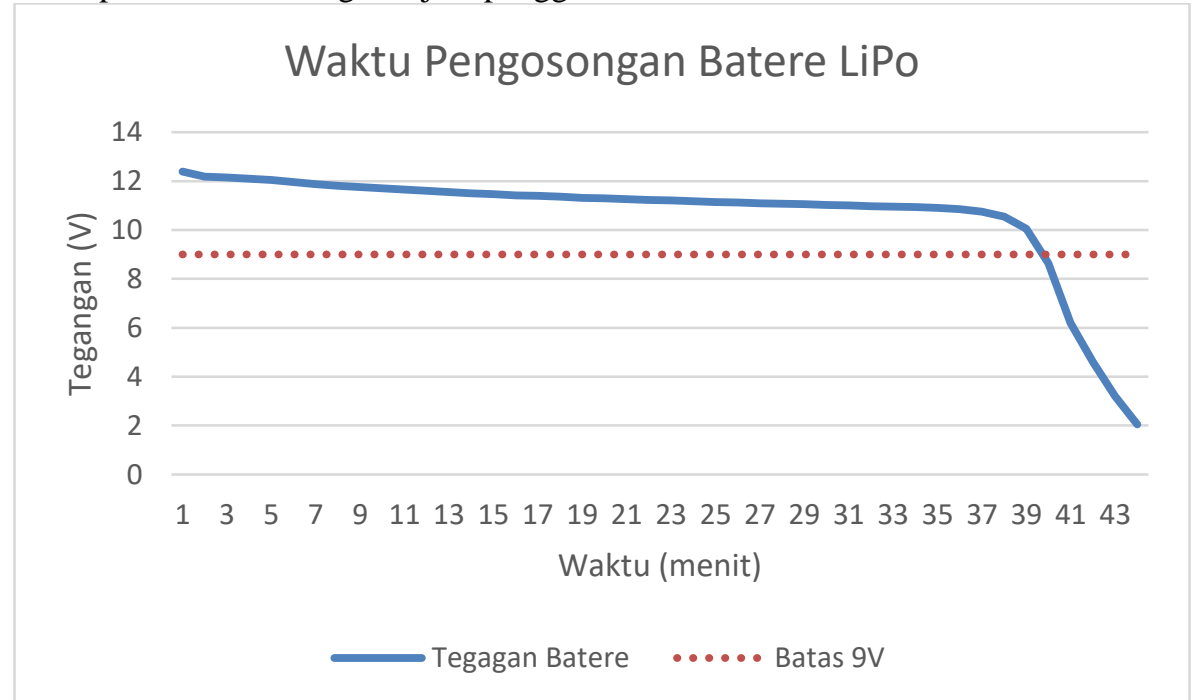

Gambar 3. Grafik pembebanan baterai LiPo $500 \mathrm{mAh} 3 \mathrm{C}$ dengan beban 4,5 Ohm

Berdasarkan hasil pengujian baterai yang ditunjukkan pada Gambar 5, menunjukkan bahwa baterai mampu bertahan pada tegangan 9 Volt dalam waktu 39 menit dengan beban 4,5 Ohm. Sistem pengunci pintu pada penelitian ini direncanakan akan membutuhan arus $1000 \mathrm{~mA}$, sehingga baterai direncanakan dapat membackup sistem selama 2 x 39 menit, atau selama 78 menit (1 jam 18 menit).

\subsection{Microcontroller Unit (MCU)}

Pengujian dilakukan dengan memberikan nilai masukan ke pin A0 yang berfungsi sebagai ADC. Tegangan yang diinputkan adalah mulai dari 0 hingga 12 Volt. Modul Wemos menggunakan batas maksimal input ADC 3,2 Volt, oleh karena itu membutuhkan rangkaian pembahgi tegangan untuk dapat membegi tegangan maksimal (12 Volt) menjadi tegangan kurang dari 3,2 Volt. Modul telah dipasangkan hambatan sebesar $320 \mathrm{KOhm}$ dari A0 ke Ground, maka sebelum masuk ke pin A0, dipasangkan resistor secara seri dengan nilai $1000 \mathrm{KOhm}$.

VAdc $=$ RWemos $/(\mathrm{R}+\mathrm{RWemos}) \mathrm{x}$ Vin

$$
\begin{aligned}
& =320 \mathrm{KOhm} /(1000 \mathrm{Kohm}+320 \mathrm{KOhm}) \times 12 \text { Volt } \\
& =2,91 \mathrm{Volt}
\end{aligned}
$$

Alat ukur yang digunakan adalah power supplay dengan output tegangan variabel ONGLAI FIXTOOL PS305DM dan multimeter SANWA CD800A untuk mengklarifikasi nilai tegangan. Hasil output bit pengubahan nilai ADC ditampilkan ke dalam serial monitor pada IDE Arduino. Adapun hasil pengujian nilai bit ADC terhadap tegangan input $0 \mathrm{~V}-12 \mathrm{~V}$ dan $>12$ Volt pada pin A0 ditunjukkan pada Gambar 4 dan Gambar 5. 


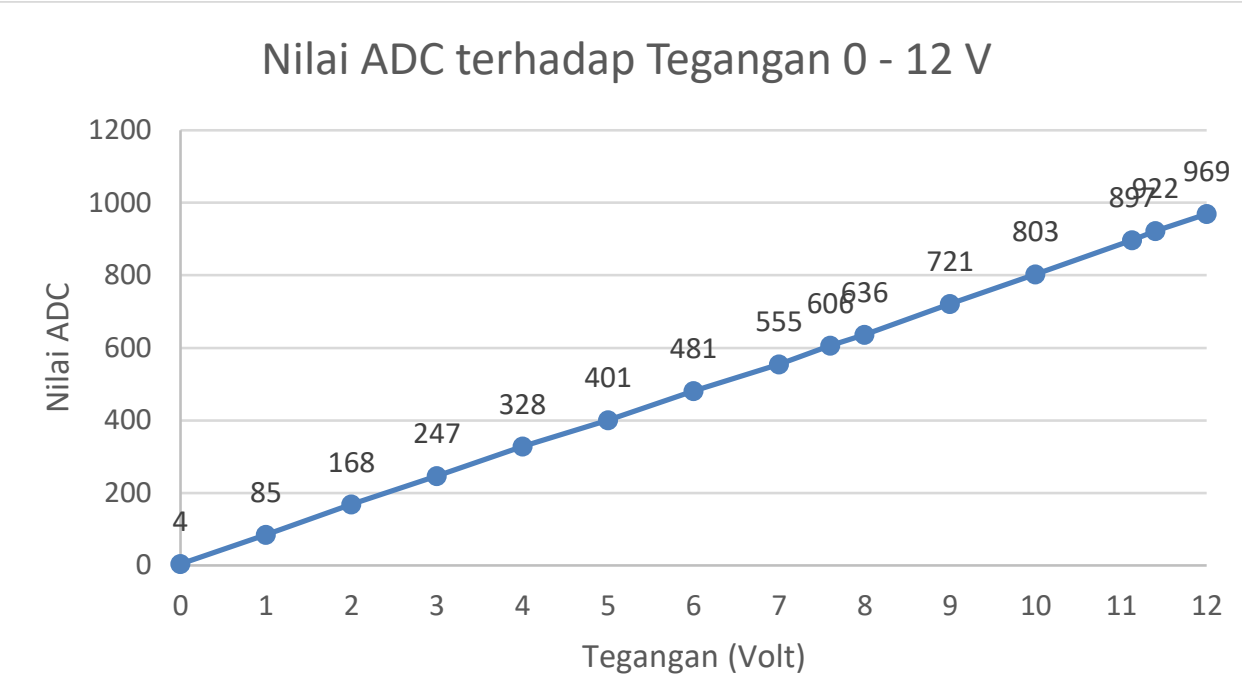

Gambar 4. Hasil pengujian nilai bit ADC terhadap tegangan input $0 \mathrm{~V}-12 \mathrm{~V}$ pada pin $\mathrm{A} 0$

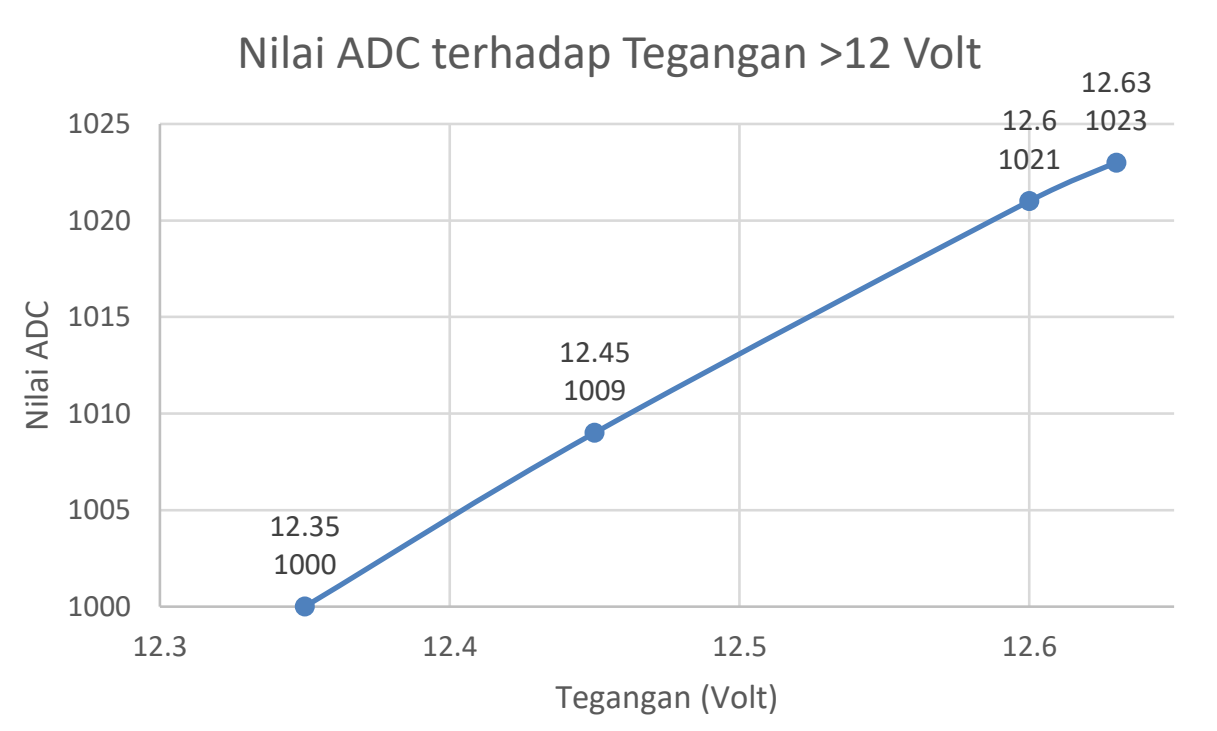

Gambar 5. Hasil pengujian nilai bit ADC terhadap tegangan input $>12 \mathrm{~V}$ pada pin A0

\subsection{Sensor Passive InfraRed (PIR)}

Sensor PIR diuji dengan cara dihubungkan dengan rangkaian antarmuka dan modul MCU. Modul MCU memiliki LED yang dihubungkan pada pin D4. Dengan mengisikan firmware ke MCU, jika object terdeteksi maka LED menyala selama 1 detik.

Pada Tabel 2, object dengan tinggi $167 \mathrm{~cm}$, rentang deteksi yang memiliki probabilitas $100 \%$ adalah antara $80 \mathrm{~cm}-160 \mathrm{~cm}$. Pada percobaan selanjutnya, dengan tinggi object $152 \mathrm{~cm}$, jarak pergerakan yang selalu terdeteksi adalah pada rentang $100 \mathrm{~cm}-160 \mathrm{~cm}$. Dari hasil percobaan tersebut, pemasangan sensor PIR dengan ketinggian $200 \mathrm{~cm}$ menghadap 45 derajat ke arah bawah memiliki rentang deteksi orang dengan ketinggian $152 \mathrm{~cm}$ hingga $167 \mathrm{~cm}$ adalah antara $80 \mathrm{~cm}-160 \mathrm{~cm}$ dari jarak sensor. 
Tabel 2. Hasil pengujian sensor PIR

\begin{tabular}{|c|c|c|c|c|c|c|c|}
\hline NO & $\begin{array}{l}\text { Ketinggian } \\
\text { Object (cm) }\end{array}$ & $\begin{array}{l}\text { Jarak orang } \\
\text { terhadap pintu } \\
(\mathrm{cm})\end{array}$ & Percobaan I & Percobaan II & Percobaan III & Percobaan IV & Percobaan V \\
\hline \multirow{9}{*}{1} & \multirow{9}{*}{167} & 20 & Mati & Mati & Mati & Mati & Mati \\
\hline & & 40 & Mati & Mati & Mati & Nyala & Mati \\
\hline & & 60 & Nyala & Mati & Nyala & Nyala & Nyala \\
\hline & & 80 & Nyala & Nyala & Nyala & Nyala & Nyala \\
\hline & & 120 & Nyala & Nyala & Nyala & Nyala & Nyala \\
\hline & & 140 & Nyala & Nyala & Nyala & Nyala & Nyala \\
\hline & & 160 & Nyala & Nyala & Nyala & Nyala & Nyala \\
\hline & & 200 & Mati & Mati & Nyala & Mati & Mati \\
\hline & & 220 & Mati & Mati & Mati & Mati & Mati \\
\hline \multirow{7}{*}{2} & \multirow{7}{*}{152} & 80 & Mati & Nyala & Mati & Nyala & Nyala \\
\hline & & 100 & Nyala & Nyala & Nyala & Nyala & Nyala \\
\hline & & 120 & Nyala & Nyala & Nyala & Nyala & Nyala \\
\hline & & 140 & Nyala & Nyala & Nyala & Nyala & Nyala \\
\hline & & 160 & Nyala & Nyala & Nyala & Nyala & Nyala \\
\hline & & 200 & Nyala & Mati & Nyala & Mati & Mati \\
\hline & & 220 & Mati & Mati & Mati & Mati & Mati \\
\hline
\end{tabular}

\subsection{Catu Daya}

Pengujian dilakukan pada nilai output SMPS, nilai output Buck Converter dan nilai output LDO. Output SMPS yang diharapkan adalah 9 - 12Volt untuk mencatu selenoid. Hasil output Buck Converter 5 Volt untuk mensuplay sensor dengan tegangan kerja TTL 5 Volt dan mensuplay mosfet untuk pensaklaran. Hasil output LDO digunakan untuk memberikan catu daya sensor dengan tegangan kerja 3,3 Volt dan MCU seperti ditunjukkan pada Tabel 3.

Tabel 3. Pengujian Catu Daya

\begin{tabular}{|c|c|c|c|c|c|c|}
\hline No & $\begin{array}{c}\text { Tegangan } \\
\text { Input (Volt } \\
\text { AC) }\end{array}$ & $\begin{array}{c}\text { Tegangan } \\
\text { Baterai (Volt } \\
\text { DC) }\end{array}$ & $\begin{array}{c}\text { Output SMPS } \\
\text { (Volt DC) }\end{array}$ & $\begin{array}{c}\text { Output Buck } \\
\text { Converter } \\
\text { (Volt DC) }\end{array}$ & $\begin{array}{c}\text { Output LDO } \\
\text { (Volt DC) }\end{array}$ & Sumber Daya Utama \\
\hline 1 & - & - & & & & Tanpa Masukan \\
\hline 2 & 220 & - & 11,95 & 4,82 & 3,23 & PLN (Grid) \\
\hline 3 & - & 12,14 & - & 4,82 & 3,23 & Baterai \\
\hline 4 & - & 9,96 & - & 4,82 & 3,23 & Baterai \\
\hline 5 & - & 8,70 & - & 4,82 & 3,23 & Baterai \\
\hline 6 & - & 7,64 & - & 4,80 & 3,23 & Baterai \\
\hline 7 & - & 6,38 & - & 4,79 & 3.23 & Baterai \\
\hline 8 & & 5,70 & & 4,15 & 3,22 & Baterai \\
\hline 9 & - & 4,00 & - & 2,50 & 2,43 & Baterai \\
\hline
\end{tabular}

Tegangan baterai minimal yang dapat digunakan sebagai catu daya untuk sistem MCU ini adalah 6 Volt untuk memenuhi kecukupan tegangan output Buck Converter $>4,5$ Volt. Tegangan MCU yang memiliki tegangan kerja 5 Volt memiliki toleransi $+10 \%$, sehingga nilai minimum untuk dapat bekerja pada sistem TTL adalah 4,5 Volt.

Walaupun tegangan baterai 6 Volt mampu menjalankan sistem MCU, namun belum dapat mengaktifkan selenoid pengunci pintu. Kebutuhan tegangan minimum untuk selenoid pengunci pintu adalah 9 Volt. Oleh karena itu, tegangan baterai yang digunakan pada tegangan ini adalah baterai yang memiliki tegangan kerja 9 Volt sudah dirasa cukup untuk memenuhi kebutuhan tegangan MCU dan Selenoid. 


\subsection{Enrollment Sidik Jari}

Tahap akhir pada pembuatan sistem pengendali dan pengaman pintu ini adalah melakukan perekaman biometric sidik jari atau yang sering disebut proses enrollment. Proses perekaman ini berguna untuk merekam pengguna yang akan mengakses pintu tersebut. Jika tidak melakukan enrollment, maka pengguna tidak dapat mengakses atau masuk melalui pintu tersebut karena sijik jari belum tersimpan di dalam databasenya. Enrollment sidik jari bisa dilakukan dengan cara membuka menu dan klik bagian enrollment seperti ditunjukkan pada Gambar 6.

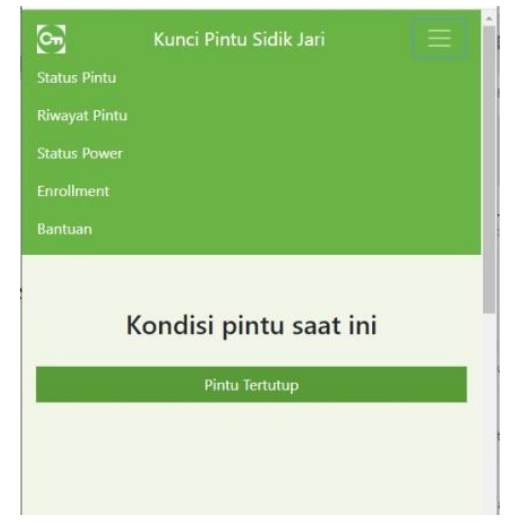

Gambar 6. Tampilan Menu Enrollment pada smartphone Android

Setelah membuka menu enrollment, pengguna bisa membaca petunjuk yang ada pada sistem (Gambar 7). Pada saat akan melakukan enrollment sidik jari, letakkan cursor pada kotak Kode Sidik Jari dibarengi dengan meletakkan sidik jari pada sensor sidik jari. Apabila sensor membaca sidik jari pengguna, maka akan muncul kode pada kotak Kode Sidik Jari secara otomatis. Berikan keterangan pada kotak Hak Akses sebagai Pengguna dan ketik nama pengguna pada kotak Nama.

Selanjutnya letakkan cursor pada kotak Kode Verifikasi, biarkan admin melakukan verifikasi data pengguna baru dengan meletakkan jari pada sensor sidik jari sehingga akan diperoleh kode verifikasinya. Kemudian setelah mendapatkan kode verifikasi lakukan submit.

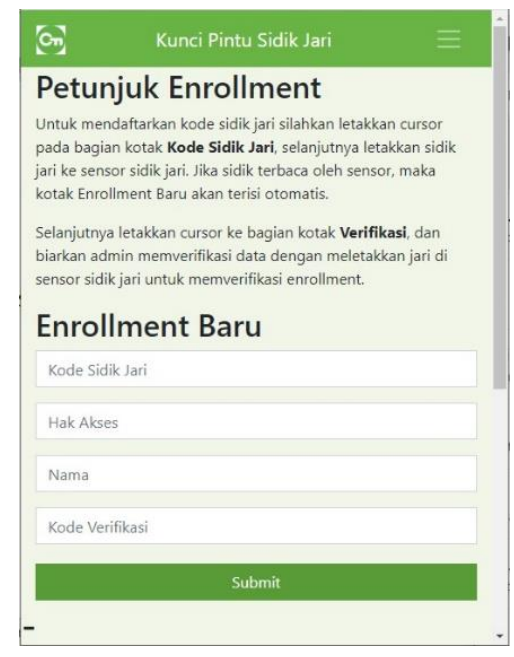

Gambar 7. Tampilan Menu Enrollment bagi Pengguna Baru

Sistem dapat melayani permintaan monitoring terhadap status pintu dalam kondisi terkunci atau tidak melalui aplikasi di smartphone Android ataupun melalui website. Selain untuk keamanan, hal ini juga diperlukan guna memonitor kondisi dari baterai dari sistem itu sendiri 


\section{KESIMPULAN}

Berdasarkan penelitian dan pembahasan tersebut di atas, maka dapat disimpulkan bahwa Electronic Door Lock mulai mampu mengunci pintu pada tegangan 9 Volt dengan arus $258 \mathrm{~mA}$. Walaupun indikator EDL mulai menyala pada tegangan 2,3 Volt, namun megnetisasi masih lemah sehingga selenoid tidak mampu menarik besi yang dipasang pada pintu.

Berdasarkan hasil pengujian baterai menunjukkan bahwa baterai mampu bertahan pada tegangan 9 Volt dalam waktu 39 menit dengan beban $4,5 \mathrm{Ohm}$. Sistem pengunci pintu pada penelitian ini membutuhan arus $1000 \mathrm{~mA}$, sehingga baterai direncanakan dapat membackup sistem selama 2 × 39 menit, atau selama 78 menit (1 jam 18 menit). Walaupun tegangan baterai 6 Volt mampu menjalankan sistem MCU, namun belum dapat mengaktifkan selenoid pengunci pintu. Kebutuhan tegangan minimum untuk selenoid pengunci pintu adalah 9 Volt. Oleh karena itu, tegangan baterai yang digunakan pada tegangan ini adalah baterai yang memiliki tegangan kerja 9 Volt sudah dirasa cukup untuk memenuhi kebutuhan tegangan MCU dan Selenoid.

Pemasangan sensor PIR dengan ketinggian $200 \mathrm{~cm}$ menghadap 45 derajat ke arah bawah memiliki rentang deteksi orang dengan ketinggian $152 \mathrm{~cm}$ hingga $167 \mathrm{~cm}$ adalah antara $80 \mathrm{~cm}-160 \mathrm{~cm}$ dari jarak sensor. Sistem pengendali dan pengaman pintu dapat dimonitor melalui smartphone atau website jika proses enrollment berhasil. Sistem ini dapat mengintegrasikan sirkuit low power yang dibangun dengan perangkat akses pintu dan platform IoT.

\section{UCAPAN TERIMAKASIH}

Ucapan terima kasih kami sampaikan kepada Lembaga Penelitian dan Pengabdian pada Masyarakat (LPPM) Universitas Muhammadiyah Purwokerto yang telah membiayai penelitian ini.

\section{DAFTAR PUSTAKA}

[1] R. Piyare and S. Ro Lee, Smart Home-Control and Monitoring Sistem Using Smart Phone. 2013.

[2] R. Muzawi and W. Kurniawan, "Penerapan Internet of Things (IoT) Pada Sistem Kendali Lampu Berbasis Mobile," J-SAKTI (Jurnal Sains Komput. dan Inform., vol. 2, p. 115, Sep. 2018.

[3] F. Masykur and F. Prasetiyowati, "Aplikasi Rumah Pintar (Smart Home) Pengendali peralatan Elektronik Rumah Tangga Berbasis WEB," J. Teknol. Inf. dan Ilmu Komput., vol. 3, no. 1, pp. 51-58, 2016.

[4] E. Susanti and J. Triyono, "Prototype Alat IoT ( Internet of Things) untuk pengendali dan pemantau Kendaraan Secara Online," in Simposium Nasional RAPI XV - 2016 FT UMS, 2017, no. December 2016, pp. 401-407.

[5] A. Anitha, "Home security sistem using internet of things," IOP Conf. Ser. Mater. Sci. Eng., vol. 263, p. 42026, Nov. 2017.

[6] F. Rozi, H. Amnur, Fitriani, and Primawati, "Home Security menggunakan Arduino Barbasis Internet of Things," INVOTEK - J. Inov. dan Teknol., vol. 18, no. 2, pp. 17-24, 2018. 
